\title{
Opening the Black Box of Leadership in the Successful Development of Local E-Government Initiative in a Developing Country
}

\author{
Johanes Eka Priyatma, Sanata Dharma University, Indonesia \\ Zainal Abidin Mohamed, Universiti Putra, Malaysia
}

\begin{abstract}
Leadership has been identified as one of the critical factors in the successful development of e-government projects especially so in developing countries. Unfortunately, empirical studies linking the outcome of egovernment projects and the role of leadership are very limited. Moreover, these studies did not comprehensively discuss the role of leadership in implementing e-government projects involving social, political, and technological transformation. Using the four moments of Actor Network Theory (ANT) translation framework, this paper presents detailed actions taken by leaders in the development of a local e-government project. The paper argues that ANT translation provides an appropriate framework to trace and monitor how leadership has been practiced effectively in an e-government project in a developing country.
\end{abstract}

Keywords: $\quad$ Actor Network Theory, Developing Country, E-Government, Leadership, Technology

\section{INTRODUCTION}

Implementation and development of e-government projects have never been an easy task. In many developed countries, e-government failed to meet the initial promise to promote better public participation and improve administrative efficiency (Bolgherini, 2007). But in developing countries, e-government development faced

DOI: $10.4018 /$ jantti.2011070101 more fundamental problems that include the lack of appropriate technological infrastructure, limited financial and human resources, and the incompatibility to their political, social and cultural environments (Nguyen \& Schauder, 2007; Imran \& Gregor; 2007). These might explain why $85 \%$ of e-government initiative in developing countries failed (Heeks, 2003). Ciborra (2005) argues that e-government thus might not yet be suitable for developing countries and Fife and Hosman (2007) even 
suggested instead to spend money for "bread" rather than for "broad-band."

However, there are some reports of successful e-government initiatives in developing countries. Gudea (2007) reported a successful cooperative approach and innovative strategy to develop home grown internet in Romania. In Ecuador, Karanasios (2007) gave evidence how small tourism enterprise successfully copes with digital divide. In Asia, two studies were documented. In India, Misra (2007) described how a self-reliance approach contributed to successful e-government implementation, while in Indonesia the success of e-government project at municipal level was reported by Furuholt and Wahid (2008).

Because of the differences in technological readiness and other factors, the implementation and development of e-government in developing countries need to adapt the strategies and approaches that have been applied in developed countries, or even develop totally new ones (Chen et al., 2006). Some researchers (Stanforth, 2006; Akhter et al., 2007; Imran \& Gregor, 2007) proposed that focus should be given more to the social and political factors surrounding the e-government projects (rather than the technological factors) as these are not only dominant but are also quite diverse. Amongst these, leadership seems to be very important and crucial as reported in several occasions. Accenture (2001) reported that leadership was the more important factor (such as political will, commitment, and accountability) than others. Studies supporting such stand were also reported by Ebrahim and Irani (2005), as they found that strong government leadership to support the organizational and procedural changes during the development of e-government was needed. Torres et al. (2005) and Kim et al. (2009) also found that strong leadership was considered as the most outstanding drivers to e-government success. Imran and Gregor (2007) further observed that leaders' vision and their willingness to initiate changes within the government sector as significant strategies to succeed in implementing an e-government project.

Although it has been convinced that leadership does play important roles in egovernment development but the number of empirical studies are rather limited (Prybutok et al., 2008). Moreover, the few that could be traced focused only on outlining some important features of an effective leadership that are related to the vision, commitment assurance or political will. They failed to describe how such features were exercised in government work setting that was much influenced by political negotiation and constrained by rules and regulations. Such has been the environment that the more static notion of leadership such as characteristics and traits are probably simpler compared to exploring the process of enacting, organizing, explaining, and managing collective actions (Pye, 2005). Therefore, the research question should be on how to explore and analyze the various leadership practices that result in the success of the e-government projects in a developing country. Answering this question will offer some valuable insights and guide for leaders involved in such projects that has to deal with many political, technical and social challenges.

Exploring and analyzing such practices require the use of an established research framework and this paper opted for the use of the Actor Network Theory (ANT). ANT was chosen mainly for its capability to capture the complexity of the interaction between the socio-cultural components as well as the involvement and the need to align the technical and political factors. Consequently, the paper also aims to expose that ANT is a useful framework to explore leadership in action in e-government projects. The focus will be on ANT's four moments of translation for it provides detailed and step-by-step framework to trace the various actions related to leadership. The exploration and analysis has been done on one successful e-government project in Indonesia (a case study approach). 


\section{LITERATURE REVIEW}

The literature review focusing on e-government, leadership and ANT aims to identify the knowledge gap in the field of leadership role and egovernment development. It is also presented to support the argument that ANT is able to provide an appropriate theoretical framework to study this knowledge.

\section{E-Government Development}

Under normal circumstances, information and communication technology (ICT) has been recognized as the main trigger and driver for e-government initiatives in delivering services to citizen. But this is no longer true since such recognition is quite myopic as it also plays significant roles in the process of transformation. Alternatively, e-government projects can also be looked from the process perspective which allows analysis up to the deliveries or the end outcomes (Grant \& Chau, 2005). Understanding these processes will help recognize the key players involved and the consequences of power redistribution amongst them (Jonas, 2000). Moreover, conceptualizing e-government projects from the process perspective will also reveal many radical prerequisite changes before a certain service can be delivered. These changes include formulating new business processes, adjusting information flows, managing changed policies, mastering new kinds of data recording, and implementing new system security measures. These intense and diverse transformational activities will then require the appropriate application of various leadership styles and characteristics (Dawes, 2002).

Despite its complexity and difficulties, many have embarked on e-government initiatives. Central as well as local governments all over the world are moving toward e-government (Jansen, 2005). Though the motive varies (Helbig et al., 2009), most e-government initiatives are directed to provide better quality services to citizens. Unfortunately, the failure rate of such initiative is also quite high as partial and total failures reach 85\% (Heeks, 2003).
Special attention should then be directed to development of e-government in developing countries so as to prevent the waste of their already limited resources.

Generally, the most common strategy proposed was to focus on assuring that bureaucratic reform happens rather than employing sophisticated technologies. Since such reform is difficult then it should be carried out by incorporating significant variables that are within the social and political context (Ndou, 2004). In other words, developing e-government initiatives should consider countries' respective characteristics and conditions (Chen et al., 2006). For example, "self-reliance" had been identified to be an effective strategy in many successful e-government developments in India (Misra, 2007). Another proposed strategy was the stakeholder participation since understanding between the roles of government agencies and its citizen created a more profound impact than technology (Akhter et al., 2007; Anthopoulos et al., 2007). However, stakeholders might have different motives and even conflicting interest (De', 2005; Priyatma \& Han, 2008). Using this understanding, Stanforth (2006) argued that any e-government initiative should recognize its nature as an information system in which its outcome will be the result of contested interest of several actors linked together in a complex network.

\section{The Role of Leadership}

Executing any of the strategies mentioned earlier needs managers with strong leadership traits since they have to change or move the present condition to a different new situation. This assertion was supported by many research findings that leadership did matter in the e-government development cycle. Leadership is necessary before, during and after e-government project implementation (Ndou, 2004). For example, the clearly articulated vision of the Singaporean government (early part of project) had inspired mindset changes and enabled government agencies to understand the move toward e-government in the country 
(Ke \& Wei, 2004). In addition, managerial innovativeness and managerial orientation (more so during the project) were the most compelling determinants of e-government adoption as reported in several municipalities (Moon \& Norris, 2005). In contrast, when analyzing the source of failures of e-government initiatives, inadequate and lack of leadership was the main constraint as reported by Gautam (2006), Gauld (2007), and Wong et al. (2007).

Despite its vital role, only few empirical studies had been conducted to investigate the role of leadership in the development of egovernment (Prybutok et al., 2008). In these studies, leadership was always discussed as an important and crucial factor for e-government development but there had no thorough description of how to practice it. Leadership as a form of social influence process was rarely discussed (Pye, 2005). Consequently, most articles on leadership links to e-government development only identified some characteristics attributed to an effective or a strong leadership. Nevertheless, understanding the role of leadership in e-government by exploring the process of enacting, organizing, explaining, and managing collective activities would contribute empirically to the data-base for e-government development. However, exploring the leadership content in egovernment development needs an appropriate approach and framework that fit the condition where power and political alignment might be very influential.

Morrel and Hartley (2006) argued that the four main theories of leadership namely traits, contingency, situational and constitutive approaches, were not suitable to understand the role of political leadership. They proposed the use of the "figurational sociology" approach to develop a model for political leadership because "figuration" refers to a network of interdependent actors and they themselves provided a useful framework to rationally talk about the complex domains that characterize the different arenas of politics. Meanwhile Drath et al. (2008) proposed a new ontology on leadership which was totally different from the common tripod ontology of leaders, followers, and shared goals. Instead, they proposed a DAC ontology in which the essential entities were three leadership outcomes:

a. Direction: widespread agreement in a collective basis on overall goals, aims, and mission;

b. Alignment: the organization and coordination of knowledge and work collectively; and

c. Commitment: the willingness of members of a collective group to subsume their own interests and benefit within the group's interest and benefit.

In addition to the above mentioned DAC model, there is also the ANT model which has been used in power negotiations and also situations involving many parties. Amongst the many characteristics that ANT possesses are its four moments of translation that perhaps can analyse the leadership role from a different perspective. While DAC's model focuses on the outcomes, ANT looks at leadership from the process perspective. Other considerations (Callon, 1986) favouring ANT are:

a. ANT analysis focuses on tracing actor's action to form and stabilize a network of relationship involving human and non-human entities (Callon, 1986; Law, 1992). This kind of analysis can be used to understand the role of leadership in any innovation activity such as an e-government development.

b. Compared to DAC's ontology, the four moments of ANT translation provide more a detailed and comprehensive framework to open up the notion of leadership that most researchers have taken for granted or normally treated as a black-box.

c. ANT has a rich vocabulary to especially deal with socio-technical reality and power redistribution that always become the main theme for e-government development and its leadership role. It is especially important as Scholl (2007) has identified that since 2002 e-government research has broadened 
its perspective beyond the role of information systems in order to incorporate the "complex socio-technical work reality" in public administration.

So far, the ANT model has been used to study how power negotiation amongst actors influences an innovation project trajectory (Law \& Callon, 1992; Heeks \& Stanforth, 2007). ANT then became a well known theory to understand information system development for it always involved interest alignment. However, there were only few studies using ANT methodology on e-government development itself since the latter is a relatively new discipline. Amongst these were:

a. Madon et al. (2004) employed ANT's four moments of translation concept to trace the development of taxation system in India.

b. Heeks and Stanforth (2007) used ANT's concept of global/local framework to understand the development of e-government by Indian Ministry of Finance.

c. Ochara (2010) used ANT to trace inscription process in the development of egovernment in Kenya and found that global actors' interest were stronger inscribed than the local actors' interest.

They concluded that ANT helped analyze the ways in which actors formed alliances and enrolled other actors to strengthen such alliances surrounding a technology innovation.

If ANT has been proven to be a useful framework to recognize the process of forming actor's alliance and mobilizing them in an innovation project, then ANT also seems to be a suitable framework to trace how leaders practice or lead an e-government initiative. Since leading is very close to the notion "of movement, of progress, of transition from one place to another, literally and metaphorically" (Pye, 2005, p. 35), then it is also close to ANT's translation (Callon, 1986, Law, 1992). ANT's four moments of translation seem more comprehensive and although they have never been used as a model for understanding leadership in general and e-government leadership in particular, it is argued that their application here will contribute to the knowledge of leadership's role in e-government projects from the process perspective as well as provide useful lessons for practitioners.

Briefly, some specific and unique characteristics of ANT that justify its use as an analytical framework are:

a. ANT perceives social reality as a complex network of relationship that always involves human and non-human entities (Law, 1992).

b. It holds radical assumption that neither human nor non-human should be given a privilege in determining the stability of certain social reality (Callon, 1986).

c. It rejects essentialism and instead embraces "relational" point of view by stating that both human and non-human entities are just an effect or outcome of a network (Law, 1992; Doolin \& Lowe, 2002).

d. ANT refers all entities (human or nonhuman) involved in this complex network of heterogeneous element as "actors" or "actor-network" (Latour, 1992).

e. It labels a stable actor-network as a black box so its analysis may focus only on its inputs and outputs (Law, 1992). Since a black box is an actor-network then its stability is also influenced by all material involved. Consequently, a relatively stable network is one embodied in and performed by a range of durable materials. One strategy to impose a stable network is then to employ some durable materials. However, this argument is not that simple because for ANT durability is also an effect and they are not automatically given by the nature of materials. That is why "the more automatic and the blacker the box is, the more it has to be accompanied by people" (Latour 1987, p. 137). The black box could be opened up and analyzed as an actor-network by tracing all its relevant actors and their relationship (May \& Powel, 2008 p. 143). 
In opening up a "black box" of reality, ANT uses the notion of translation (Callon, 1986) to make sense why certain social reality finally becomes stable/unstable over time. Translation can be described as a process in which actor(s) mobilizes resources or another actor-network to form allies that result in a stabilized actornetwork. For example, in developing functional e-government systems there must be actor(s) who mobilizes the needed resources (money, ICT, programmer, stipulations, et cetera) in such a way that these resources become an alliance working together and influence each other to result in a working e-government. Therefore, translation explores the ways that the networks of relations are composed, maintained, and made more durable over time. The translation process involves four moments (phases), namely:

a. Problematization. In this moment one or more key actors define the nature of the problem and the roles of other actors to fit the proposed solution. The solution is offered in such a way that all actors that participated will be subjected to some centralised control mechanism labelled as an "obligatory passage point (OPP)."

b. Interessement. Here all actors identified in the first phase are given specific roles and identities and the strategies that need to be acted upon which will attract them. This attraction is implemented through some interessement strategies that will lead them to the next phase.

c. Enrolment. The success of the interessement strategies will result in the enrolment of actors to participate in establishing a stable network of alliance. However, the stability of this alliance depends on the negotiation process to define their roles in the network.

d. Mobilization. Once the proposed solution gains wider acceptance, then an even larger network of absent entities are created through some actors acting as spokespersons for others.
There are many criticisms of ANT from different perspective such as in neglecting the influence of broader social structure to the local situation (McLean \& Hassard, 2004), its suitability for interpretive stance (Cordella \& Shaikh, 2006), its contribution to the critical theory of organization (Whittle \& Spicer, 2008). However, there are only two relevant critics related to this research namely the problem of inclusion/exclusion of actors and its symmetrical treatment to human and non-human. The first critic relates to the decision of who to include and who to exclude in ANT analysis. Law (1992) argues that an investigator surely cannot follow actors everywhere and consequently he/ she should in practice employ certain ordering, sorting, or selection. Meanwhile Miller (1996) suggests that investigative work should be directed at contextualizing the specific event as a way of cutting the endless network.

The second critic has been the subject of controversy for it is morally problematic to make no distinction between human action and the behaviour of things (Collins \& Yearley, 1992; Knights \& Murray, 1994). Actor-network scholars have argued that they accept the divisions and distinctions, but only when they are understood as effects (Law, 1992) and they refuse to consider the distinctions a priori (Latour, 1996). Law (1992) also argues that Sociology is not Ethics and the concern of ANT is not on ethical issue. For ANT, equal treatment between people and objects is an analytical stance, not an ethical position.

\section{METHODOLOGY AND DATA GATHERING}

Data were gathered from a one stop service project located at Badan Pelayanan Terpadu / $B P T$ (Bureau of Integrated Services) of Sragen regency Central Java Indonesia. The project (from now referred as Sragen One Stop Service (SOSS)) was selected since it was recognized as being the most successful regional e-government development in Indonesia by central 
Table 1. Sample of themes and its extracted text

\begin{tabular}{|c|c|c|}
\hline Theme & Extracted Texts & Source \\
\hline Problematization & $\begin{array}{l}\text { All of these are the idea of the Bupati. Actually the authority to issue } \\
\text { license is himself but then he delegated to the respected office. However, } \\
\text { consequently public who apply license should go to many offices with } \\
\text { uncertain processes. These conditions created high cost. When the Bupati } \\
\text { retracted these authorities, the head of offices might lose their financial } \\
\text { opportunities as you said. It is what we want to reform. }\end{array}$ & $\begin{array}{l}\text { Section Head } \\
\text { of Customer } \\
\text { Services }\end{array}$ \\
\hline Interessement & $\begin{array}{l}\text { We got financial incentive and it is in line with ministry regulation that } \\
\text { staff working at one stop service unit may be given additional salary and } \\
\text { its amount depend on each regency capability. }\end{array}$ & $\begin{array}{l}\text { Sub-section Head } \\
\text { of Certificates } \\
\text { Issuance }\end{array}$ \\
\hline Enrolment & $\begin{array}{l}\text { The expansion of one stop service unit from only as a unit in } 2003 \text { and } \\
\text { finally became a bureau of integrated services in } 2006 \text { was a result of the } \\
\text { commitment from our top executive and legislative leaders. Thus its suc- } \\
\text { cess came from both executive and legislative as well as from all partici- } \\
\text { pating heads of offices who delegated their authority in issuing license to } \\
\text { our unit. All of these are meant to provide easy, quick, transparent, and } \\
\text { not complicated services. }\end{array}$ & $\begin{array}{l}\text { Sub-section Head } \\
\text { of Certificates } \\
\text { Issuance }\end{array}$ \\
\hline Mobilization & $\begin{array}{l}\text { We are their servants. We are public servants and we try to provide } \\
\text { good services. If this situation is changed then public will be disap- } \\
\text { pointed. So we really expect that there will be no action to destroy all } \\
\text { of these. We should not think that this is part of our rival, because in } \\
\text { reality it could happen. }\end{array}$ & Head of BPT \\
\hline Performance & $\begin{array}{l}\text { Luckily, the customer satisfaction evaluation done every six month } \\
\text { showed the increasing performance. From the last two evaluations, it } \\
\text { reached } 83,995 \% \text { in December } 2007 \text { and } 84,005 \% \text { in June } 2008 \text {. }\end{array}$ & $\begin{array}{l}\text { Sub-section Head } \\
\text { of Information, } \\
\text { Documentation } \\
\text { and Customer } \\
\text { Services }\end{array}$ \\
\hline
\end{tabular}

government and many private institutions. Since it is located in relatively remote regency and has limited resources, the success of SOSS has been attributed to its leadership approach (Furuholt \& Wahid, 2008). Therefore, SOSS is a suitable case for this study.

Data gathered include factual (numerical), textual, audio, and visual event. They were collected by observing at the project site, inspecting archival documents, and recording semi structured interviews for two months. The interviews were conducted in local language and included 19 human actors who were involved in the development of SOSS. This included nine management staffs of SOSS (the head, secretary, all six sub-section heads, and two staffs from personnel administration sub-section and customer service respectively), four heads of offices (Electronic Data Processing, Health, Industry and Commerce, Civil Registration), a computer programmer coordinator from Electronic Data Processing Office, two citizens applying license, a guest doing comparative study, and the leader of Sragen regency referred to commonly as "Bupati." All interview sessions lasted from 30 to 90 minutes. Recorded interviews and the narration of video presentation were transcribed fully before they were analyzed. Since SOSS was perceived as a complex socio-technical reality, topical themes (Rychards, 2005 p. 92) which were used to extract information from transcribed interviews were developed based on the four moments of ANT translation and information system elements. Table 1 provides sample of themes and its extracted texts.

Since following the actor(s) is the basic guideline of an ANT analysis (Callon, 1986; Latour, 2005) then what will be described in the analysis section is mainly tracing the decisions and actions taken by the Bupati of Sragen 
starting from the conceptualization to the implementation of SOSS. In tracing Bupati's works, some other connected human and non-human actors will also be followed. Following Law (1992) in handling inclusion/exclusion of actors, only those that have significant contribution to the design and implementation of SOSS will be included. Meanwhile, the description of each moment of translation will be linked to its suitable context as a way of interpreting the event appropriately as proposed by Miller (1996).

\section{DATA ANALYSIS I: CASE DESCRIPTION OF SRAGEN ONE STOP SERVICES (SOSS)}

Sragen Regency located at the eastern part of Central Java Province is one of the 330 regencies in Indonesia, covers an area of $941.55 \mathrm{~km}^{2}$ and has 22 kecamatan (sub-districts), 208 kelurahan (smaller areas within each sub-district). Its population has remained quite stable over the last two years with 855,244 inhabitants and a density of 908 per square $\mathrm{km}$. About 412,206 people ( $48 \%$ of total) are employed, with $51 \%$ of them in the agricultural sector, $19 \%$ in services, and $13 \%$ in hotel, trade and restaurants. The agricultural sector contributes $34.46 \%$ to the total RGDP (Regional Gross Domestic Product) with a value of IDR $835,005.58$ million (US\$ 83,500.6 thousand). Meanwhile, per capita income is only IDR 929,230.79 or about US\$ 100.

Using the strategic planning process approach, the local administration of Sragen has developed a set of guidelines for its development. These include the formulation of its vision, mission, strategy and development priorities that can be easily accessed from www.sragen. go.id. For the year 2006 - 2011, Sragen's vision is to be a smart regency and its mission is to have its citizens achieve excellence, be productive and prosperous. This mission is being realized through the implementation of a set of strategies and one of them is creating an innovative entrepreneurial administration providing excellent public services.
As a former business man, the Bupati of Sragen was fully aware of how complicated and difficult it is to deal with government bureaucratic procedures. After being inaugurated as Bupati in 2001, he decided to do a major reform to his administration. One of his objectives was to establish a simple yet effective and efficient process of issuance of various licenses for the general public and investors. He believes that enforcing simple investment procedure would trigger more business activities that in turn would increase local government revenue. Although in 2000 Sragen already had the so-called Integrated Services Unit or One-Roof services unit (Unit Pelayanan Terpadu/UPT) but its performance was considered as unsatisfactory. The main drawback of this unit was its inability to provide transparent and simple procedures.

On June 16th, 2002 the Bupati of Sragen established an ad-hoc team comprising of nine respected government officers to study the matter. The team came up with a proposal to modify the existing "one-roof" to a "one-door" service. The previous one-roof service unit had no authority to issue any licenses but the new one-door service unit does. As the consequence for the formation of the one-door service unit, former offices which used to issue licenses had to delegate this authority to this new service unit. The delegation was not simple since it brought some consequences to the staff working in the respective offices, ranging from the change of administrative procedures to the lost of authority and some financial benefits. The Bupati resolved this problematic situation by reminding all heads of offices that in principle the ultimate authority of issuing license was the Bupati. It was then his prerogative to retract that authority and delegate it to another office. Bupati finally endorsed Bylaw No. 17 / 2002 which transferred the authority for issuing licenses where the issuance of licenses to the one-door service unit of SOSS.

The new UPT then gradually became popular because of its effective and efficient services. At the beginning, it handled only 15 licenses but now it issues 59 licenses and 10 
certificates (non-license such as birth certificate and citizen identity card). In line with its increasing volume of services, with Regional Government Regulation (RGR) No. 15/2003 the status of this unit was upgraded to that of an office and it began to be called KPT/Kantor Pelayanan Terpadu (One-Door Service Unit) and then later with RGR No. 6/2006 it was made into a bureau (and called BPT/Badan Pelayan Terpadu).

Some indicators could be attributed to verify the success of SOSS. From the citizen's point of view, the simple, transparent, and accountable services had satisfied them. Based on two recent service satisfaction survey involving 150 respondents conducted twice a year, the customer satisfaction index scored $83.995 \%$ and $84.005 \%$ respectively. From some government and non-government organizations' point of view, SOSS was also considered a good model of a quality public service provider. From the economic point of view, SOSS managed to directly and indirectly increase revenue for the local government. In 2002 Sragen's revenue was only IDR 22.6 billion but in 2005 it rose to IDR 72.8 billion. Within 3 years, it increased by $300 \%$. One small and medium enterprise (SME) owner testified that the SOSS personnel had helped him obtain financing for his business said:

"I managed to get a loan from a bank immediately because all the required documents were timely provided by the SOSS personnel and it saved a lot of my time. For me, SOSS is really helpful."

\section{DATA ANALYSIS II: USING THE FOUR MOMENTS OF ANT ANALYSIS ON LEADERSHIP INVOLVEMENT}

Each of the four moments of ANT translation will be used consecutively to review and analyze the various activities that the Bupati of Sragen has done but looking only from the leadership perspective which is the focus of this paper.
The central problem faced by SOSS was to serve the public better by providing simple, transparent, accountable, and one-stop license services. In addition to the endorsement by the Indonesian central government since 1998, the establishment of SOSS was also motivated by the Bupati's concern to reform local government public services. He fully believed that introducing a company-like work culture to the government service sector was possible and ICT should be used intensively as a main driver for such an initiative. This was due to his vast experience in the private sector and his full commitment to develop SOSS to support the prosperity of his regency.

Bupati was much perceived by most of his staffs as a genuine but decisive, creative, innovative, confident, ICT-literate, and powerful leader. This is portrayed in the city billboard welcoming commuters to Sragen. His emergence from a laptop screen while holding a stack of rice crops is a "rich text" that reflects his concern and his stance toward the use of ICT. He was also described as an unselfish passionate leader, who is concerned with his country's development problems. He wanted to make Sragen better and supports the overall development of the country. His popular motto was "what Sragen does should colour Indonesia."

By ensuring that SOSS issues businessrelated licenses efficiently, the Bupati hoped to attract more investors and this eventually would increase the local government's revenue. This increase was an important agenda of every regency leader since the stipulation of the Autonomy Act No.32/2004. This Act delegates local government administrations to manage some public affairs, ranging from regency development, general health services, primary and secondary education, civil administration to local investment administration.

\section{Problematization Moment}

The most crucial part in ensuring SOSS's success was to get support from heads of various offices that were authorised to issue licenses. It was common that not only the senior staff from 
these offices but even some lower-level staffs abused this "power" and make it difficult to issue license for their own benefit. The other problem was to run the one-door service efficiently just like a private entity. To manage this situation Bupati conducted many meetings to promote, explain and solicit support involving related heads of offices, some important personnel from his office and other local legislative bodies. He then problematized the establishment of SOSS by defining the roles of all involved actors. The description of the roles and relationship of some important actors (human and otherwise) involved are as follows:

\section{a) The heads of participating offices}

There were 10 different offices directly involved in the issuance of business licenses. At first, the heads of these offices were not willing to delegate their authority to SOSS personnel. But the Bupati reminded them that in principal he had the sole authority to issue the licenses but had delegated and empowered to the various offices for logistical reasons and smoother operations. He autocratically decided to retract the authority given and pass it on to his own SOSS personnel. However, he clarified that each office still had the authority to monitor the operation of every related activities. In addition, they still participated in the decision making process and fees collected would be posted as revenue for the respective office which formerly had the authority. This "winwin" problematization proposed by the Bupati resulted in no significant resistance from various offices so that the head of Industry, Commerce and Cooperation Office who should delegate his authority to SOSS gave his commitment by saying:

"As part of regency administration which is determined to improve its public service through the establishment of SOSS unit, we have no objection. Moreover, in fact the Bupati is the one who hold the authority to issue licenses.
If now the Bupati wants to retract this authority and pass it on to SOSS unit then it is not a problem for us."

\section{b) SOSS staffs}

As of May 2009, SOSS had 31 staffs managing 59 various licenses and 10 certificates. The educational qualification of these staffs varied: six had master degree, seventeen with bachelors, four with vocational degree, and four with high school qualification. [At the initial establishment in 2002, the number of SOSS staffs was only 21]. All of them had good performance records and worked at different offices before they were selectively recruited. All SOSS staffs got additional enumerations above their monthly salary as incentive. The incentive made them have a take-home pay higher than other employees holding similar posts in the government services.

\section{c) Technology infrastructure}

SOSS had an appropriate ICT infrastructure. Every staff in SOSS was provided with a computer set that was connected to the local computer network and the internet. The local computer network was part of a larger network connecting almost all important local government offices and village offices across the regency. Although the ICT infrastructure and its related information systems were regarded as the most important non-human technological actors, there were also other important actors such as the air-condition, the CCTV system, and the TV sets. The technology infrastructure seemed to cooperate well since Bupati regarded it as an important actor for his government innovation initiative. He perceived that ICT played important roles not only as a facilitator but also as a controller. His vision of Sragen as "Being a Smart Regency" reflected how strongly he believed to the important role of technology in general and ICT in particular to support the regency development. 


\section{d) Stipulations}

These are conditions, provisions or terms that are created to be placed on to SOSS's shoulders for serious considerations. Historically, the notion of improving public services quality came from Indonesian President Instruction No. $1 / 1995$. It was then operationally stipulated by the Ministry of State Apparatus Empowerment' Decree No. 81/1998. However, the notion of one-stop service was first articulated by the Ministry of Home Affairs through Decree No. 25/1998. In the context of Central Java Province Government, the Governor issued Decree No. 28/1999 on the guidelines for the establishment of integrated public service units for local governments.

Based on Bupati's Decree No. 17/2002, Sragen reformed the existing one-stop service to the one-door service approach. Meanwhile, there was also Presidential Instruction No. $3 / 2003$ which instructs the implementation of e-government across all government agencies. Since then Bupati and local government of Sragen had issued many stipulations as SOSS underwent dynamic development in term of its organizational structure, its services, and its relation to other offices. The Central Government finally appreciated what had been practiced in SOSS and even Ministry of Home Affairs issued Decree No. 24/2006 on the guidelines of the formation of one-door integrated public services. This stipulation significantly adopted some best practices from SOSS. Unfortunately, the Central Government then issued Decree No. $41 / 2007$ on the new guidelines on the establishment of local government offices and departments structure, and based on this decree, the one-stop service was just an optional unit with a one-roof approach and had no direct authority to issue license. Therefore, this stipulation was not in line with Ministry of Home Affairs' Decree No. 24/2006. Sragen local government and with some others then urged the Ministry of Home Affairs to respond to this contradicting regulation. The Ministry of Home Affairs responded by issuing Decree No. 20/2008 that facilitated the establishment of a one-stop service either in the form of an office or even a bureau. Though this last stipulation resolved the conflicting regulation but the outlined structure of one-stop service office or bureau was less powerful than to the one Sragen had. This condition brought a sort of disappointment to some staffs at SOSS since it might lower their echelon rank and that would decrease their salaries.

e) KPDE (Kantor Pengolahan Data Elektronik/Electronic Data Processing Office)

KPDE was responsible for managing ICT infrastructure across Sragen regency as well as developing e-government systems to support local administration. Most of the license processing systems were jointly developed by these two offices. However, the permanent role of KPDE toward SOSS was to maintain the ICT infrastructure and also to assure the data and systems integrity among various e-government systems in Sragen. Kantaya, (short for "Kantor Maya / Virtual Office"), which was developed and maintained by KPDE, was the most frequently used systems to support SOSS. It enabled departments and village offices to easily share data in which the Bupati could remotely monitor. KPDE also plays vital role in assisting Sragen regency's vision to be a "smart government" which is linked with the intensive use of ICT to support its development programs. The performance of SOSS had significant impact on KPDE since it would reflect the success of KPDE in developing e-government in Sragen. Therefore, KPDE positively supported SOSS and was an important actor.

\section{f) Citizens of Sragen}

Although many citizens of Sragen wanted to serve the public more, but interestingly, none was ever directly involved in the development process. Their only direct participation was involved in a survey to evaluate SOSS performance twice a year. Although SOSS had provided many communication channels such as email, SMS (Short Messaging System), and 
hot-lines facilities to enable individuals to articulate their concerns, so far their participation and feedbacks were very limited.

\section{g) Visitors to SOSS}

Although at the design stage visitors did not play any significant role to the actor-network developed by the Bupati, eventually, especially after SOSS received a lot of recognition, they had an important role in shaping its continuous development. What made them important was not because of their numbers (more than 1000 for the last three years) but their intention to do a comparative study and this also created unique interessement. Having many visitors to recognize their performance brought a valuable psychological effect to most SOSS staffs as they felt supported, successful, and knowledgeable when being praised. A customer service staff member even commented:

\section{"We should treat all our visitors well because if even one visitor got wrong impression of us then he could easily spread around bad news that would ruin our reputation."}

After identifying all actors involved, Bupati made himself an indispensable member and defined the obligatory passage point (OPP) as "how to provide simple, transparent, and be accountable services for processing various licenses for the citizens of Sragen." The Bupati was aware that either positive or negative interest of those actors to this OPP determined the success of this initiative. Figure 1 presents these network of interest toward OPP from all involved actors.

The problematization process showed how bureaucratic reform introduced by Bupati was an essential component of this e-government initiative. It also showed that the reform had to deal with legal, procedural, organizational, managerial, as well as mental and cultural issues. Although the reform was only about providing license at regency level but it was not an easy one as similarly reported by many researchers (Grant \& Chau, 2005; Stanforth, 2006; Yildiz, 2007). This reform was actually harder to manage within the Javanese culture context where most people do not want any conflict with others since their valued scenario is to live in harmony (Kartodirjo, 1984 p. 185). However, the Bupati seemed to be able to manage this reform successfully. Though many interviewees acknowledged that the reform was successful mainly because of the Bupati's decisive stance and a "win-win" power sharing with heads of offices but the contextual understanding suggests that it was also because of the way staffs perceived the Bupati's role as their leader. From the Javanese culture perspective, a public leader is always perceived as "God chosen" and is never merely part of a human democratic system (Ali, 1986 p. 203). Consequently, a good leader should be not only strong, powerful, decisive, but also the same time kindhearted since he/she is to represent God in governing people and nature at the same time. To some extent, the Bupati's authoritarian style of leadership, was not only accepted by his staffs but was also supported. This situation, where the citizens understand the role and importance of their leader, originates from an agricultural society. Although only $51 \%$ of the people in Sragen work in the agricultural sector, the rest still also live in a very close relationship with this culture.

\section{Interessement Moment}

The Bupati attempted to influence and stabilize all the actors he defined in the problematization process by introducing several interessement strategies. These strategies extended and materialized the hypothesis he made concerning the success of SOSS which included:

- License inquiry should be simple, fast, and transparent,

- Involved offices should support by returning their authority to the Bupati,

- SOSS staffs can be transformed to become professional workers, 
Figure 1. Problematization network of SOSS

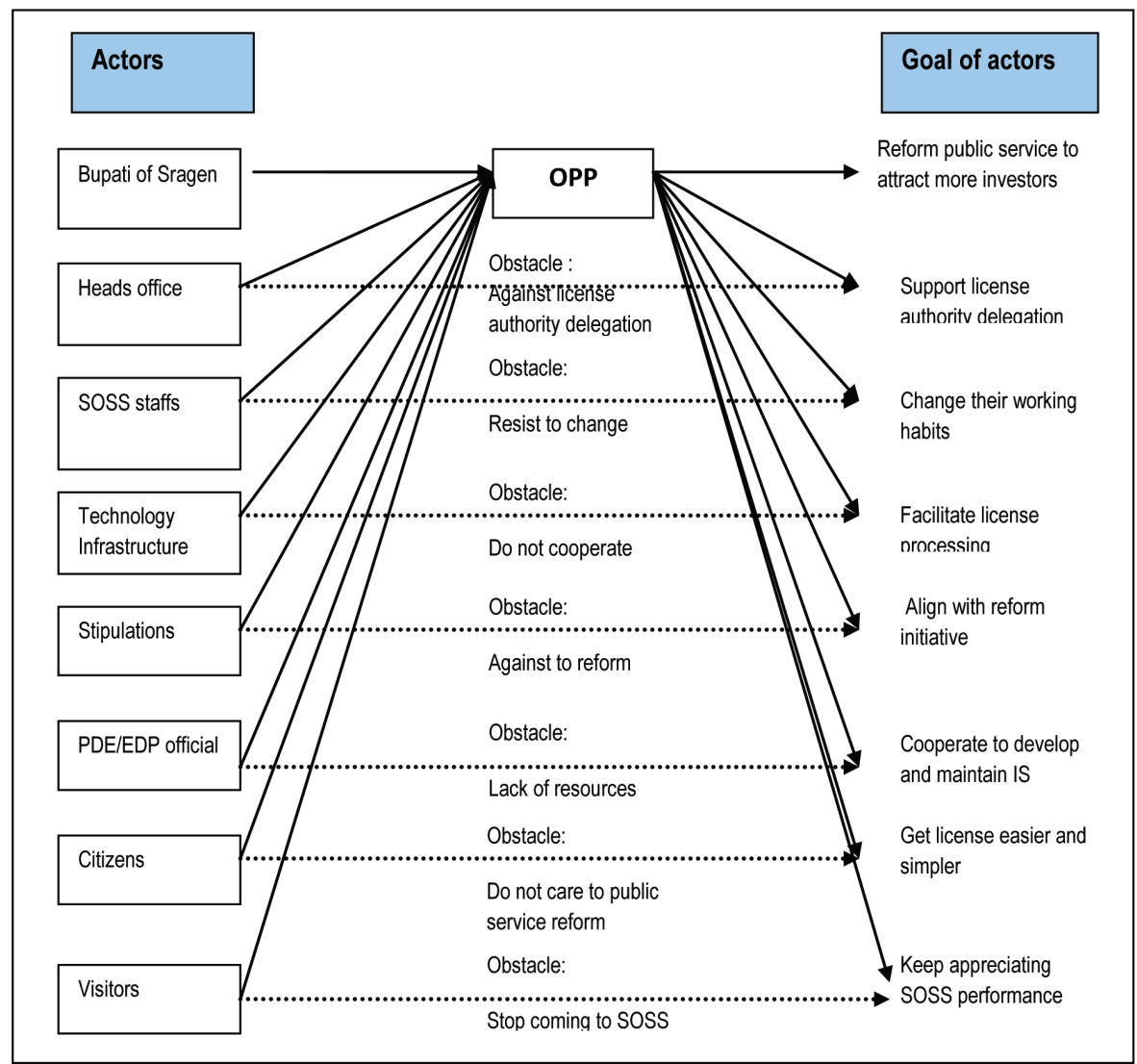

- $\quad$ ICT systems and private sector practices can be fully adopted,

- Excellent license services would attract more investors.

Under these hypotheses, the Bupati implemented three new important interessement strategies which are as follows:

a) Granting SOSS unit an authority to issue licenses after retracting that authority from various offices.

The Bupati reminded each office that conceptually he was the one who held the authority to issue licenses. Therefore, the Bupati had the legal right to transfer it to SOSS. Nevertheless, fees collected from license processing, before they were transferred to Local Finance Office, would be posted to the account of the respective office that formerly issued the licenses and each related office would be represented in the technical team to review license application and to recommend its approval.

b) Facilitating SOSS to adopt corporate work culture and management equipped with new reward system.

All SOSS staffs (new and old) should participate in a series of compulsory training programs to change their mind-set from being served to providing service, to improve their skills in serving public, and to master ICT. 
To get real experience on how to serve public excellently, these staffs participated in a week internship training program at Gianyar Regency in Bali. Every week SOSS staffs would also join an in-house training program given by internal speakers and motivators with different specializations. As part of the efforts to change their work culture, SOSS staffs wore new office attire, different from that of other government employees. They wore a long-sleeved shirt and a neck-tie in order to look like professional workers in a private company. They also received a supplement to their previous monthly salary as incentive to maintain their performance and to prevent corruption practices.

To maintain its good performance, SOSS had a good management and control systems. First, in 2005 it adopted the ISO managerial standards. Although only 16 (out of 62) licenses processing procedures were certified by ISO, the standard were applied to all other licenses processing procedures. Second, the Bupati, heads of office, and monitoring team could easily monitor SOSS performance using many channels such as through the weekly and monthly reports, site visits, or via CCTV. Third, SOSS conducted performance evaluation twice a year using 14 performance variables and involving at least 150 respondents.

c) Providing incentives to members of the business community who wants to initiate operation in Sragen.

Since the main objective of SOSS was not merely to provide excellent services for license processing and issuance, but also to increase business investment, the Bupati also provided some incentives to business community to complement the quality services offered by SOSS. He provided free business licenses for those who were new. He also had set up a business complex at Kalijambe, located about 30 $\mathrm{km}$ from Sragen with its appropriate land size and infrastructure. He even reminded people in Sragen to stop asking companies to provide any community facility since his administration should be the one responsible for such a request. As a result, the number of business-related license application increased significantly and resulted in fee growth of $300 \%$ in 2004 .

The Bupati elegantly managed to transfer licenses-issuing authority from several offices to SOSS because of his awareness and knowledge on how power and authority can be conceptually distributed and exercised within the local government systems. Uniquely, although the authority to issue non-license (certificates) was not transferable to SOSS because of some stipulations and restriction from the central government, in practice this authority was digitally transferable. It happened whenever SOSS issued new certificates which were signed digitally not by the SOSS head but by the head of the Civil Registry Office. This solution could be considered quite creative as it innovatively used ICT in this authority reconfiguration. In this case, ICT played an important interessement device. However, this should not be considered as merely an ICT innovation but it reflected more on how the Bupati exercised his leadership effectively in his relationship with office heads. From the interessement moment point of view, ICT was used effectively to make this relationship a reality. In other words, the Bupati was able not only to exercise his formal power that arose from his positions of authority (Silva, 2007) as the top leader in Sragen but he also successfully implemented some devices of interessement to create favourable balance of power (Callon, 1986) amongst his actors.

\section{Enrolment Moment}

Generally, all implemented interessement devices resulted in enrolment from respective actors. However to elaborate further, all actors that participated in the enrolments will be represented when coming up with each interessement strategy or policy. The interessement strategy to grant SOSS an authority to issue license finally resulted in enrolment from all involved offices but the heads of offices negotiated some issues (as deliberated earlier). The authority transfer should not result in a reduction of their income. 
Most staffs at SOSS seemed happily enrolled to the implementation of corporate work culture introduced by the Bupati. Perhaps the initial incentive provided for them was an important factor to their enrolment but later most staffs no longer considered it as their main drive. By then they were not only fully committed to serving citizens like the way private sector did but also had internalized their style of service deep down in their heart under the notion of "ikhlas" or sincerity. This "ikhlas" value has been strong and embedded character of the Javanese way of life (Kartodirjo, 1984 p. 188) and since all staffs of SOSS are Javanese, the need for quality public service could be easily enrolled into them. Not only did this success in enrolment made them serve the public excellently but it also made them proud. One of the many similar comments recorded when they were asked about their feeling of their new work culture. Below is one such comment from a staff handling licenses related to health services.

\section{"...I am proud that I can serve public better} especially now when we are recognized locally and nationally. For us, it is invaluable. There is a sort of satisfaction if the way I serve public is nationally adopted as the best practice. Such is beyond our expectation since initially we just wanted to make an innovation but now it is recognized nationally and even it has been referred to by Home Affairs Minister's Decree No 26/2006."

Their deep-rooted work culture at SOSS contributed significantly to the successful alliance from other actors such as from ICT infrastructure and system, the ISO-based license processing, and some regulations. Indeed, the information systems they were using were basically simple but their positive attitude toward this system then made them easily accept its limitation, such as failed connection, viruses, and frequent system modifications. Although the adopted ISO management system adopted had created some administrative burden, they found it very useful since it made them have the full control of license processing. In addition, despite the Central Government's introduction of regulation No. 41/2007 which does not adequately appreciate the SOSS organizational structure, they perceived it as a challenge and not merely as a threat.

\section{Mobilization Moment}

Throughout the project cycle, only few individuals were directly involved and became the spokesperson to represent other individuals who chose to be silent (Callon, 1986). Some of these representations will be reviewed to understand the role of legitimate spokespersons.

During the designing stage of SOSS, the Bupati represented the citizen of Sragen in general and business community in particular who demanded excellent licenses-processing service. The Bupati was a legitimate spokesperson of Sragen's citizen since people had voted him as their top leader. Though there was no process to appoint him as representative of the business community, his long experience as a manager in a private company made him a legitimate spokesperson for them. After being inaugurated as Bupati, he was officially also a legitimate spokesperson of central and provincial government, which had a concern to improve the quality of public services.

The Bupati represented the citizens to negotiate with some offices represented by their respective heads. Of course, every head office was a legitimate spokesperson for all the staffs working in his/her respective office. The Bupati negotiated with the head of offices to provide better license-processing service by asking them to select their qualified staff to work at SOSS. The selected staffs from each office would then be a legitimate representative of the various offices respectively. For the subsequent stage of the development, the SOSS head then became a legitimate spokesperson for all his staffs to negotiate with other representatives.

In promoting his idea to establish SOSS, the Bupati stressed that ICT would be intensively used. In many occasions the Bupati unintentionally became a legitimate spokesperson of voiceless ICT too, especially when he himself 
frequently used ICT to present his ideas. On one occasion he even removed the out-dated over-head projector from his meeting room to condition all his staffs to used laptop and LCD projectors. The Bupati also acted as a legitimate and powerful spokesperson of ICT when he strongly encouraged KPDE to come up with a computer-based system which enabled him to digitally monitor the performance of all offices at any time.

The Bupati was a legitimate spokesman for the heterogeneous population where he mobilizes local legislative members to approve the expansion of SOSS from a unit in 2002 into an office in 2003 and finally into a bureau in 2006. This expansion has enabled SOSS to manage more licenses and have more personnel to consolidate the organizational structure with higher echelon staffs. To negotiate with local assembly members, the Bupati represented the citizens of Sragen, who demanded quality licenses-processing; the staffs of SOSS, who were willing to work professionally; the provincial and central governments, which encouraged local government to reform public service; the office heads who supported license authority transfer; ICT; and also KPDE, which supported the SOSS operation.

The above description shows how Bupati became an effective leader and was listened to because he had been "the head" of many groups of actors. He was able to combine the demand of the citizens, ICT, KPDE, SOSS staffs, rules and regulation, assembly members, and office heads. These chains of mediated relationship that finally resulted in an ultimate spokesperson could be referred as a progressive mobilization (Callon, 1986) of actors who formed alliance to successfully deliver excellent licenses-processing procedures. All these actors were first disbanded and then reassembled at a certain place at a particular time at the SOSS office (opened from Monday to Saturday, and from $7.30 \mathrm{am}$ to $02.30 \mathrm{pm}$ ).

\section{CONCLUSION}

The use of ANT methodology has helped to monitor how a leader stabilizes the whole actor- network of members of local e-government initiative by identifying all involved whether human or otherwise. Their dynamic participation to the network has been noted and much influenced by their enrolment to some interessement strategies directed to achieve common goal defined in the obligatory passage point. It has also helped to understand how effective leadership may take advantage of mobilization process in which a legitimate spokesperson plays important role in stabilizing actor-network. The Bupati became an effective leader when managed to formulate and implement some strong and contextual interessement strategies that accommodated various issues: economic (an additional pay), managerial (the ISO standard), technical (the ICT infrastructure and its system), legal (local and central regulations), as well as spiritual (the notion of "ikhlas") and ideal ("colouring" Indonesia). An effective leadership in e-government development is then closely related to its capability to manage problematization process and to introduce strong and contextual interessement strategies.

Among the four moments of translation, the problematization process is the most crucial one. An effective leader should be careful in proposing e-government's problematization in general and it's obligatory passage point in particular since they will become referrences and affect the selection of effective interessement strategies. Putting a bureaucratic reform as the central issue of e-government problematization seems more appropriate and effective than considering it as an issue of technological innovation. Consequently, translating bureaucratic requires strong leadership because it intensively involves how power negotiation will be managed in certain political and social contexts.

Although ANT has been criticized many times as providing a Machiavellian ontology in understanding power (Whittle \& Spicer, 2008), which is considered no longer appropriate for it fails to pay adequate attention to the notion of emancipation and participation, Silva (2007) however argues that a Machiavellian view of power is key for making sense of legitimate 
and illegitimate power. Since power is always an essential part in understanding leadership in government setting then the Machiavellian ontology of ANT become an appropriate framework to understand leadership. It is especially so to understand how leadership is exercised in the design and implementation of an e-government in which the social relationship is much influenced by patron-client type coming from an agriculture society such as in Sragen regency.

\section{REFERENCES}

Accenture. (2001). eGovernment leadership: Rhetoric vs reality - Closing the gap. Retrieved from http:// www.accenture.com/Global/Research_and_Insights/By_Industry/Government_and_Public_Service/GovernmentsRhetoric.htm

Akther, M. S., Onishi, T., \& Kidokoro, T. (2007). E-government in a developing country: Citizencentric approach for success. International Journal on Electronic Governance, 1(1).

Ali, F. (1986). Refleksi Paham "Kekuasaan Jawa" dalam Indonesia Modern. Jakarta, Indonesia: P.T. Gramedia.

Anthopoulos, L. G., Siozos, P., \& Tsoukalas, I. A. (2007). Applying participatory design and collaboration in digital public services for discovering and re-designing e-government services. Government Information Quarterly, 24, 353-376. doi:10.1016/j. giq.2006.07.018

Bolgherini, S. (2007). The technology trap and the role of political and cultural variables: A critical analysis of the e-government policies. Review of Policy Research, 24(3), 259-275. doi:10.1111/ j.1541-1338.2007.00280.x

Callon, M. (1986). Some elements of sociology of translation: Domestication of the scallops and the fishermen of St Brieuc Bay. In Law, J. (Ed.), Power, action and belief: A new sociology of knowledge? (pp. 196-223). London, UK: Routledge.

Chen, Y. N., Chen, H. M., Huang, W., \& Ching, R. K. H. (2006). E-government strategies in developed and developing countries: An implementation framework and case study. Journal of Global Information Management, 14(1), 23-46. doi:10.4018/ jgim. 2006010102
Ciborra, C. (2005). Interpreting e-government and development:Efficiency, transparency or governance at a distance? Information Technology \& People, 18(3), 260-279. doi:10.1108/09593840510615879

Collins, H., \& Yearley, S. (1992). Epistemological chicken. In Pickering, A. (Ed.), Science, practice and culture. Chicago, IL: University of Chicago Press.

Cordella, A., \& Shaikh, M. (2006). From epistemology to ontology: Challenging the constructed "truth" of ANT. Retrieved from http://is2.lse.ac.uk/ WP/PDF/wp143.pdf

Dawes, S. S. (2002). The future of e-government. Retrieved from http://www.ctg.albany.edu/publications/reports/future_of_egov/future_of_egov.pdf

De'. R. (2005). E-government systems in developing countries: Stakeholders and conflict. In M. A. Wimmer, R. Traunmüller, Å. Grönlund, \& K. V. Andersen (Eds.), Proceedings of the $4^{\text {th }}$ International Conference on Electronic Government (LNCS 3591, pp. 26-37).

Doolin, B., \& Lowe, A. (2002). To reveal is to critique: Actor-network theory and critical information systems research.Journal of Information Technology, 17, 69-78. doi:10.1080/02683960210145986

Drath, W. H., McCauley, C. D., Palus, C. J., Velsor, E. V., O'Connor, P. M. G., \& McGuire, J. B. (2008). Direction, alignment, commitment: Toward a more integrative ontology of leadership. The Leadership Quarterly, 19, 635-653. doi:10.1016/j. leaqua.2008.09.003

Ebrahim, Z., \& Irani, Z. (2005). E-government adoption: Architecture and barriers. Business Process Management Journal, 11(5), 589-611. doi:10.1108/14637150510619902

Fife, E., \& Hosman, L. (2007). Public private partnerships and the prospects for sustainable ICT projects in the developing world. Journal of Business Systems, Governance and Ethics, 2(3).

Furuholt, B., \& Wahid, F. (2008). E-government challenges and the role of political leadership in Indonesia: The case of Sragen. In Proceedings of the 41st Hawaii International Conference on System Sciences.

Gauld, R. (2007). Public sector information system project failures: Lessons from a New Zealand hospital organization. Government Information Quarterly, 24, 102-114. doi:10.1016/j.giq.2006.02.010 
Gautam, V. (2006). E-governance 'paradigms' revisited: Constraints and possibilities. In Sahu, G. P. (Ed.), Delivering e-government. New Delhi, India: Global Institute of Flexible Systems Management.

Grant, G., \& Chau, D. (2005). Developing a generic framework for e-government. Journal of Global Information Management, 13(1), 1-30. doi:10.4018/ jgim.2005010101

Gudea, S. (2007). Internet access on the cheap: The power of the co-op. Journal of Business Systems, Governance and Ethics, 2(3).

Heeks, R. (2003). Most e-government-fordevelopment project fail: How can risks be reduced?Manchester, UK: Institute for Development Policy and Management.

Heeks, R., \& Stanforth, C. (2007). Understanding e-government project trajectories from an actornetwork perspective. European Journal of Information Systems, 16(2), 165-177. doi:10.1057/palgrave. ejis. 3000676

Helbig, N. C., Gil-García, J. R., \& Ferro, E. (2009). Understanding the complexity in electronic government: Implications from the digital divide literature. Government Information Quarterly, 26, 89-97. doi:10.1016/j.giq.2008.05.004

Imran, A., \& Gregor, S. (2007). A comparative analysis of strategies for e-government in developing countries. Journal of Business Systems, Governance and Ethics, 2(3).

Jansen, A. (2005). Assessing e-government progress- why and what. In Proceedings of the Norsk Konferanse for Organisasjoners Bruk Av IT.

Jonas, D. K. (2000). Building state information highways: Lessons for public and private sector leaders. Government Information Quarterly, 17(1), 43-67. doi:10.1016/S0740-624X(99)00026-X

Karanasios, S. (2007). Ecuador, the digital divide and small tourism enterprises. Journal of Business Systems, Governance and Ethics, 2(3).

Kartodirjo, S. (1984). Modern Indonesia \& transformation. Yogyakarta, Indonesia: Gadjah Mada University Press.

Ke, W., \& Wei, K. K. (2004). Successful e-government in Singapore. Communications of the ACM, 47(6), 95-99. doi:10.1145/990680.990687
Kim, S., Kim, H. J., \& Lee, H. (2009). An institutional analysis of an e-government system for anti-corruption: The case of OPEN. Government Information Quarterly, 26, 42-50. doi:10.1016/j. giq.2008.09.002

Knights, D., \& Murray, F. (1994). Managers divided: Organisation politics and information technology management. Chichester, UK: John Wiley \& Sons.

Latour, B. (1987). Science in action. Cambridge, MA: Harvard University Press.

Latour, B. (1992). Where are the missing masses? Sociology of a few mundane artefacts . In Bijker, W., \& Law, J. (Eds.), Shaping technology, building society: Studies in socio-technical change. Cambridge, MA: MIT Press.

Latour, B. (1996). The trouble with actor-network theory. Soziale Welt, 47(4), 369-381.

Latour, B. (2005). Reassembling the social: An introduction to actor-network-theory. New York, NY: Oxford University Press.

Law, J. (1992). Notes on the theory of the actornetwork: Ordering, strategy, and heterogeneity. Systems Practice, 5(4). doi:10.1007/BF01059830

Law, J., \& Callon, M. (1992). The life and death of an aircraft: Anetwork analysis of technical change. In Bijker, W. E., \& Law, J. (Eds.), Shaping technology, building society: Studies in socio-technical change. Cambridge, MA: MIT Press.

Madon, S., Sahay, S., \& Sahay, J. (2004). Implementing property tax reforms in Bangalore: An actornetwork perspective. Information and Organization, 14,269-295. doi:10.1016/j.infoandorg.2004.07.002

May, T., \& Powel, J. L. (2008). Situating social theory (2nd ed.). New York, NY: McGraw-Hill.

McLean, C., \& Hassard, J. (2004). Symmetrical absence/symmetrical absurdity: Critical notes on the production of actor-network accounts. Journal of Management Studies, 41(3). doi:10.1111/j.14676486.2004.00442.x

Miller, P. (1996). The multiplying machine. Accounting, Organizations and Society, 22(3-4), 355-364. doi:10.1016/S0361-3682(96)00030-X 
Misra, D. C. (2007, December 10-13). Sixty years of development of e-governance in India (19472007): Are there lessons for developing countries? In Proceedings of the International Conference on Theory and Practice of Electronic Government, Macao, China.

Moon, M. J., \& Norris, D. F. (2005). Does managerial orientation matter? The adoption of reinventing government and e-government at the municipal level. Information Systems Journal, 15, 43-60. doi:10.1111/j.1365-2575.2005.00185.x

Morrell, K., \& Hartley, J. (2006). A model of political leadership. Human Relations, 59(4), 483-504. doi:10.1177/0018726706065371

Ndou, V. (2004). E-government for developing countries: Opportunities and challenges. Electronic Journal on Information Systems in Developing Countries, 18(1), 1-24.

Nguyen, T. T., \& Schauder, D. (2007). Grounding e-government in Vietnam: From antecedents to responsive government services. Journal of Business Systems, Governance and Ethics, 2(3).

Ochara, N. M. (2010). Assessing irreversibility of an e-government project in Kenya: Implication for governance. Government Information Quarterly, 27(1), 89-97. doi:10.1016/j.giq.2009.04.005

Priyatma, J. E., \& Han, C. K. (2008). ANT and egovernment research in developing countries: Acase in BIMP-EAGA . In Rahman, A. A., Ali, N. A., \& Han, C. K. (Eds.), Management research issues (pp. 187-222). Malaysia: UPM Press.

Prybutok, V. R., Zhang, R., \& Ryan, S. D. (2008). Evaluating leadership, IT quality, and net benefits in an e-government environment. Information \& Management, 45,143-152. doi:10.1016/j.im.2007.12.004
Pye, A. (2005). Leadership and organizing: Sensemaking in action. London, UK: Sage.

Rychards, L. (2005). Handling qualitative data: $A$ practical guide. London, UK: Sage.

Scholl, H. J. (2007). Central research questions in e-government, or which trajectory should the study domain take? Transforming Government: People . Process and Policy, 1(1), 67-88.

Silva, L. (2007). Epistemological and theoretical challenges for studying power and politics in information systems. Information Systems Journal, 17, 165-183. doi:10.1111/j.1365-2575.2007.00232.x

Stanforth, C. (2006). Using actor-network theory to analyze e-government implementation in developing countries. Massachusetts Institute of Technology . Information Technologies and International Development, 3(3), 35-60. doi:10.1162/itid.2007.3.3.35

Torres, L., Pina, V., \& Royo, S. (2005). E-government and the transformation of public administrations in EU countries Beyond NPM or just a second wave of reforms? Online Information Review, 29(5), 531-553. doi:10.1108/14684520510628918

Whittle, A., \& Spicer, A. (2008). Is actor network theory critique? Organization Studies, 29(4), 611-629. doi:10.1177/0170840607082223

Wong, K., Fearon, C., \& Philip, G. (2007). Understanding e-government and e-governance: Stakeholders, partnerships and CSR. International Journal of Quality \& Reliability Management, 24(9), 927-943. doi:10.1108/02656710710826199

Yildiz, M. (2007). E-government research: Reviewing the literature, limitations, and ways forward. Government Information Quarterly, 24, 646-665. doi:10.1016/j.giq.2007.01.002

Johanes Eka Priyatma has been lecturing in the field of Information Systems at Sanata Dharma University Yogyakarta Indonesia since 1994. Since then he lead the design and implementation of information system to support his university academics and management systems until 2006. He also involved the development of e-government system in Indonesia since 2005. He is currently taking a PhD at Graduate School of Management of University Putra Malaysia in the area of e-government looking particularly on the potential contribution of Actor Network Theory to its development. During his study he has been actively participating in several international conferences and writing some journal articles. 
Zainal Abidin Mohamed is currently a professor in management and the former Dean of the Graduate School of Management at University Putra Malaysia (UPM). Holds a Bachelor degree in Agricultural Science (Malaya 74), MBA (Wis 76) and PhD (Edin 88). Active in teaching, advisory and research activities in the areas of strategic management, supply chain, innovations and entrepreneurship. Have held several administrative positions in UPM and at University Utara Malaysia (while on secondment in 1999-2002). Attended the Harvard Executive programme in 1984, International Teachers Programme at INSEAD, 1991 and was attached to SPEA in 1995 at University of Indiana, Bloomington under the Fulbright sponsorship for research in Reengineering during his sabbatical. Also an active trainer/coach in EDP programmes for in-house training, such as MAS, PETRONAS, MAYBANK, TELEKOM, Port Klang Authority, as well as public departments and SMEs. Conducted similar programmes in Zimbabwe and Ethiopia. Have twenty-eight publications in the form of three books, twelve chapters in books and the rest in academic journals. Chief editor of the Asian Journal of Case Research, Fellow of EDI of the World Bank, and President of Case writers'Association of Malaysia since 2003. 